Editoriais. O financiamento da pesquisa em doenças tropicais no Brasil, José Duarte de Araújo, e Haemagogus leucocelaenus em ambiente urbano, Pedro Luiz Tauil. Revista da Sociedade Brasileira de Medicina Tropical 18: 1-5, Jan-Mar, 1985

esforços no sentido de uma definição clara das prioridades para pesquisa, da busca de um melhor entrosamento entre os pesquisadores e os usuários da pesquisa - os órgãos de controle - e, particularmente, de facilitår o acesso do pesquisador na área de doenças tropicais ao conjunto das fontes de financiamento existentes dentro ou fora do pais. it has been working to obtain a clear definition of research priorities. It is also seeking a better understanding and cooperation between the scientists and the users of research - the disease control agencies and, particularly, to facilitate the access of scientists from the field of Tropical Diseases to the financing agencies both in Brazil and abroad.

\section{HAEMAGOGUS LEUCOCELAENUS EM AMBIENTE URBANO}

Por ocasião do XXI Congresso da Sociedade Brasileira de Medicina Tropical, recentemente realizado em São Paulo, foi apresentado, como tema livre, um trabalho intitulado "Haemagogus leucocelaenus em área urbana de municípios do interior do Estado de São Paulo", de autoria de Moretti L A, Martins M M, Magro L G e Amaral A L M, da Superintendência de Campanhas de Saúde Pública - SUCAM Diretoria Regional de São Paulo.

Os autores descreveram a descoberta de larvas do mosquito acima referido, nas sedes dos municipios de Turmalina e Populina, nos meses de março e abril de 1984, durante as atividades de rotina de vigilância do Aedes aegypti naquele Estado.

É nossa intenção ressaltar a importância desse fato, repetido em outras cidades do Brasil, como Fortaleza, e em cidades de outros paises da América, como no Equador.

Tratando-se de espécie de mosquito primitivamente silvestre e encontrado na copa das árvores, susceptivel ao virus da febre amarela, torna-se muito importante, como salientaram os autores do trabalho, uma continuidade das investigações entomológicas, bem como outros estudos sobre a susceptibilidade das cepas, encontradas em ambiente urbano, ao vírus da febre amarela, a fim de poder-se avaliar o risco de transmissão urbana da doença por esses mosquitos.

É do nosso conhecimento que a SUCAM está promovendo gestões junto ao Instituto Evandro Chagas, da Fundação SESP, do Ministério da Saúde, no sentido de promover estudos sobre a susceptibilidade das cepas de $\mathrm{Hg}$. leucocelaenus encontradas em área urbana.

\section{HAEMAGOGUS LEUCOCELAENUS IN AN URBAN ENVIRONMENT}

At the XXI Congresso da Sociedade Brasileira de Medicina Tropical held recently in São Paulo, a free communication was presented entitled "Haemagogus leucocelaenus in urban areas of municipalities in the interior of São Paulo State" by Moretti L A, Martins $\mathbf{M}$ M, Magro L $\mathbf{G}$ and Amaral A L M, from the Superintendência de Campanhas de Saúde Pública SUCAM of São Paulo.

The authors described the finding of larvae of the mosquito referred to above in houses in the municipalities of Turmalina and Populina in the months of March and April of 1984, during the routine vigilance activities for Aedes aegypti in that State.

We wish to draw attention to this important finding which has also occurred in other Brazilian cities, like Fortaleza, and in cities of other American countries such as Ecuador.

This species of mosquito is primarily sylvatic, being encountered in tree tops. It is susceptible to the virus of yellow fever. As the authors emphasise, it is very important to continue these entomological investigations. Also the susceptibility of such urban dwelling mosquitoes to yellow fever virus must be studied to evaluate the risk of urban transmission by this species.

To this aim SUCAM is collaborating with the Instituto Evandro Chagas, Fundação SESP, Ministry of Health to stimulate studies, of the susceptibility of strains of $\mathrm{Hg}$. leucocelaenus encountered in urban areas. 
Todos esses fatos merecem uma atenção muito especial, pois caso esteja se desenvolvendo uma mudança de hábitos desse mosquito silvestre, de forma significativa, além do problema já existente das inúmeras reinfestaçōes pelo $A$ e. aegypti, teremos que enfrentar essa nova situação, possivelmente com mudanças importantes na estratégia de controle da febre amarela nas Américas.
This problem merits attention because if this sylvatic mosquito is changing its habits to a significant degree, this could increase the risk of urban yellow fever as a result as well as the numerous reinfestations by $A$ e aegypti. We would have a new vector to contend with which could lead to important changes in the strategy to control yellow fever in the Americas.

Pedro Luiz Tauil

Sociedade Brasileira de Medicina Tropical 